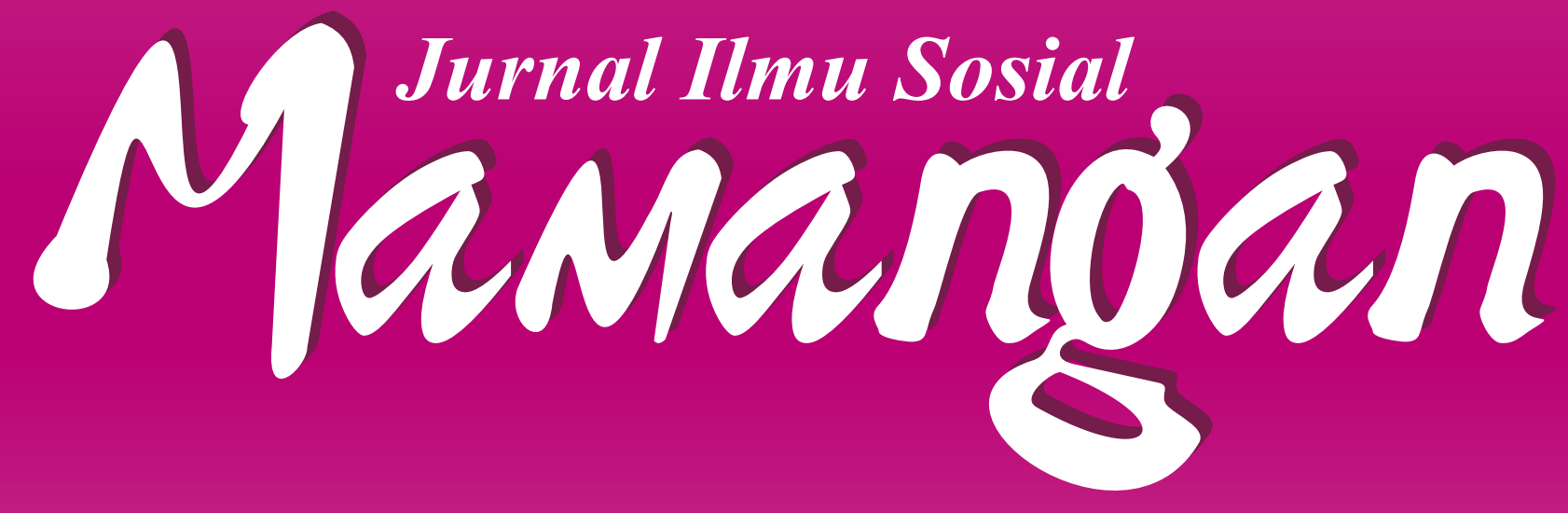

Seni Tradisi, Jatidiri dan Strategi Kebudayaan

Heddy Shri Ahimsa-Putra

Sejarah dan Nilai Songket Pandai Sikek

Silvia Devi

Budaya dalam Lintasan Sejarah: Booming Nonton Bioskop di Padang Tempo Dulu

Meri Erawati

Paradoksal Gaya Sosial Global; Kajian Budaya dalam Memahami Kesadaran Kolektif di Tengah Booming Batu Akik

Silfia Hanani

Gaya Kehidupan Malam Remaja di Kota Padang; Suatu Kajian Subkultur di Tempat Hiburan Malam Kota Padang

Faishal Yasin

Perlawanan Kaum Muda terhadap Hegemoni Radikalisme Agama dalam Bentuk-Bentuk Budaya Populer

Yusar

Gaya Interaksi \& Integrasi Sosial Anak Muda Rantau: Kasus Mahasiswa Kost di Air Tawar Barat, Kota Padang Darmairal Rahmad 


\section{PROGRAM STUDI PENDIDIKAN SOSIOLOGI STIIIP PGRI SUMATEPA BARAT}

\section{Visi}

"Menjadi Program Studi yang terkemuka di bidang pendidikan keguruan sosiologi dan kompetitif secara nasional di tahun 2026"

\section{Misi}

$>$ Melaksanakan dan mengembangkan pendidikan dan pengajaran yang berbasis kepada pengembangan kecerdasan intelektual (hard skill) dan kecerdasan emosional (soft skill) untuk memperoleh kecakapan hidup (life skill),

> Melaksanakan dan mengembangkan penelitian dan pengabdian di bidang pendidikan dan pengajaran serta bidang lain sesuai dengan keilmuan fakultas dan program studi,

$>$ Mengembangkan Ilmu Pengetahuan, Teknologi, dan Seni (IPTEKS) yang dilandasi profesionalisme,

$>$ Menyelenggarakan perguruan tinggi yang akuntabel, efisien, efektif, transparan, relevan dan mandiri,

$>$ Mengembangkan kerjasama dengan berbagai lembaga/instansi terkait dan stakeholders untuk keberlanjutan pelaksanaan program dan/atau pembukaan program studi baru. 


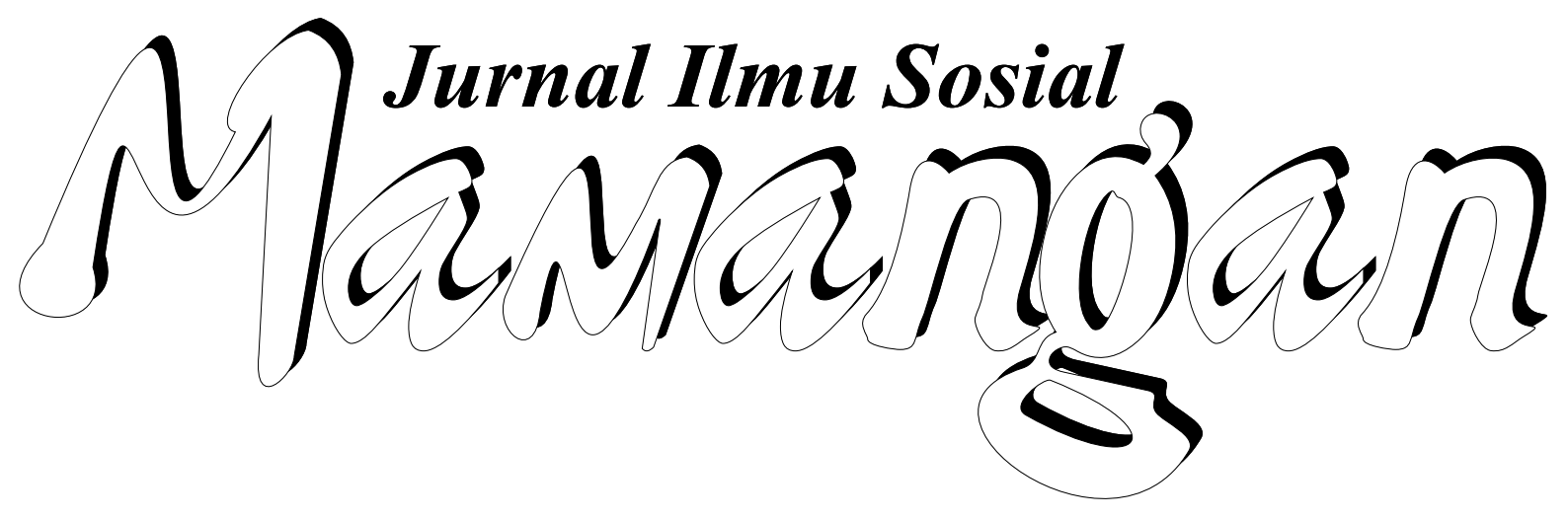




\section{一挑一 \\ Jurnal Ilmu Sosial Mamangan}

Volume 2, Nomor 1, Januari-Juni 2015

\section{Mitra Bestari}

Prof. Dr. Afrizal, MA. (FISIP, Unand Padang)

Prof. Dr. Badaruddin, M. Si. (FISIP, USU Medan)

Dr. A. Latief Wiyata, M. Si. (Universitas Jember, Jember)

Dr. Fikarwin Zuska, M. Si. (FISIP, USU Medan)

Nurus Shalihin, M. Si., Ph.D. (Fak. Ushuluddin IAIN Imam Bonjol Padang)

Dr. Semiarto A. Purwanto, M. Si. (FISIP, UI Jakarta)

Dr. Wahyu Wibowo, M. Si. (Universitas Nasional, Jakarta)

\section{Dewan Redaksi}

Dr. Zusmelia, M. Si.

Dr. Maihasni, M. Si.

Firdaus, S. Sos., M. Si.

\section{Pemimpin Redaksi/Editor}

Firdaus, S. Sos., M. Si.

\section{Anggota Redaksi}

Ariesta, M. Si.

Dian Kurnia Anggreta, S. Sos., M. Si.

Faishal Yasin, S. Sos., M. Pd.

Ikhsan Muharma Putra, M. Si.

Rio Tutri, M. Si.

Sri Rahayu, M. Pd.

Yuhelna, MA.

ISSN: 2301-8496

viii +109 halaman, $21 \times 29 \mathrm{~cm}$

\section{Alamat Redaksi:}

Laboratorium Program Studi Pendidikan Sosiologi, STKIP PGRI Sumbar Kampus STKIP PGRI, Jl. Gunung Pangilun, Padang, Sumatera Barat

Email: redaksimamangan@gmail.com \& daus_gila@yahoo.com

\section{Penerbit:}

Laboratorium Program Studi Pendidikan Sosiologi, STKIP PGRI Sumbar 


\section{PENGANTAR REDAKSI}

$\mathrm{K}$

ebudayaan merupakan produk yang dihasilkan oleh manusia, baik dalam bentuk ide, tindakan maupun karya. Yang terakhir disebut merupakan produk kebudayaan yang paling kongkrit dan termati dalam masyarakat. Kebudayaan terus diproduksi oleh manusia sesuai dengan zaman dan tantangannya untuk memenhi kebutuhan hidup mereka saat itu. Oleh karena kebudayaan terus diprosukdi oleh manusia, maka kebudyaan terus berdinamika sesuai dengan ruang dan waktu. Proses dinamika tersebut kadang berjalan dengan lambat dan kadang berjalan dengan cepat.

Respon terhadap dinamika kebudayaan juga berbeda berdasarkan kelompok. Paling tidak terdapat tiga kelompok berbeda menurut redaksi dalam menanggapi dinamika kebudayaan. Kelompok pertama adalah kelompok yang resah dengan dinamika kebudayaan, kedua kelompok yang senang dengan dinamika dan ketiga kelompok yang berada pada titik keseimbangan dalam melihat dinamika kebudayaan. Terlepas dari tiga kelompok yang ada, redaksi menyadari bahwa dinamika kebudayaan pasti akan berlangsung kapan saja dan dimana saja. Oleh karenanya, banyak bentuk kebudayaan baru yang dihasilkan dan banyak kebudayaan lama ditinggalkan.

Menyadari bahwa proses dinamika kebudayaan akan menghasilkan bentuk kebudayaan yang baru dan kebudayaan lama ditinggalkan, pada edisi ini redaksi mengambil tema-tema tulisan menyangkut kebudayaan. Tulisan-tulisan yang ada bicara dalam tema kebudayaan dengan berbagai perspektif dan pendekatan. Pendekatan itu mulai dari sejarah, hingga perlawanan, sehingga tulisan-tulisan dalam edisi ini disumbangkan oleh mereka dengan latar belakang yang berbeda.

Tulisan pertama disumbangkan oleh Prof. Heddy Shri Ahimsa-Putra, Guru Besar UGM. Dalam tulisannya Ahimsa-Putra menguraikan seni tradisi di Indonesia. Menurutnya terdapat tiga seni tradisi di Indonesia, yaitu seni tradisi Ageng, seni tradisi Alit dan seni tradisi suku. Seni-seni tradisi tersebut memiliki fungsi sebagai atraksi wisata, sebagai jati diri komunitas dan sebagai sumber inspirasi untuk penciptaan dan pengembangan seni-seni baru. oleh karenanya, 
seni tradisi tersebut perlu dilestarikan dan dikembangkan. Pelestarian dan pengembangan seni tradisi di Indonesia saat ini terkendala oleh banyak hal. Dalam tulisannya, Ahimsa-Putra menawarkan beberapa alternatif yang dapat dilakukan untuk pelestarian dan pengembangan seni tradisi.

Tulisan kedua ditulis oleh Silvia Delvi, Peneliti Balai Kajian Sejarah Sumatera Barat. Devi dalam artikelnya membahas tentang songket sebagai produk kebudayaan di nagari Pandai Sikek Sumatera Barat. Dalam tulisannya, Delvi lebih menekan pada aspek sejarah dan nilai songket di Pandai Sikek. Menurutnya, Songket Pandai Sikek sudah ada sejak pertengahan abad ke-19. Proses produksi songket Pandai Sikek sangat eksklusif untuk warga Pandai Sikek dan tidak ditransfer kepada orang lain. Hal ini karena terdapat rahasia pembuatan dan nilai pada masing-masing motif yang diproduksi. Jika ingin pandai menenun songket Pandai Sikek, satu-satunya cara adalah dengan menjalin hubungan keluarga dengan orang Pandai Sikek.

Tulisan berikutnya ditulis oleh Meri Erawati, Dosen Sejarah STKIP PGRI Sumbar. Erawati menulis cerita nonton bioskop pada tempo dulu di Kota Padang. Dalam tulisannya, Erawati membahas tentang perkembangan bioskop dan jenis film yang ditayangkan di Kota Padang pada era 1970-2000. Yang menarik dari uraian Erawati adalah cerita tentang bagaimana simbol-simbol muncul di seputaran bioskop dan kecenderungan style orang-orang menonton bioskop pada masa itu. Tidak terkecuali itu, temuan Erawati tentang kejahilan-kejahilan penonton terhadap penonton lainnya memperkaya tulisan Erawati.

Tulisan keempat ditulis oleh Silfia Hanani, dosen Sosiologi IAIN Bukittinggi. Hanani menulis tentang batu akik yang sangat popular dan booming beberapa waktu belakangan. Dalam tulisannya, Hanani menguraikan bagaimana nalar individu dipengaruhi oleh nalar kolektif tentang batu akik, dampaknya semua orang-minimal- memperbincangkan batu akik. Lebih dalam, Hanani juga membahas pemaknaan orang terhadap batu akik yang mengalami pergeseran dari pemaknaan yang sakral ke pemaknaan keindahan dan seni. Masing-masing jenis batu kemudian menjadi identitas bagi penanda bagi daerah asal dimana batu akik ditemukan. Di bagian lain, Hanani juga mendiskusikan paradoks batu akik dengan persoalan kehidupan dan lingkungan.

Tulisan kelima ditulis oleh Faishal Yasin, Dosen Sosiologi STKIP PGRI Sumbar. Tulisan Yasin membahas tentang gaya yang diampilkan oleh remaja di hiburan malam seperti café, bilyar dan diskotik. Secara detail Yasin menguraikan bagaimana para remaja berpakaian, memilih makanan dan musik di masing-masing lokasi hiburan. Yasin kemudian menghubungkan gaya tersebut dengan kultur induk -Minangkabau- dimana remaja tersebut hidup dan berkembang. Dalam analisisnya, Yasin menyebutkan bahwa gaya tersebut merupakan penyimpangan dari kultur induk mereka.

Tulisan keenam ditulis oleh Yusar, dosen Sosiologi Universitas Padjajaran. Yusar menulis perlawawan anak muda terhadap hegemoni radikalisme anak muda di tiga kota di Indonesia. Temuan Yusar, perkembangan tekhnologi dimanfaatkan oleh anak muda secara kreatif dalam melakukan perlawanan terhadap radikalisme agama di tiga kota tersebut. Anak muda menggunakan berbagai media berbasis tekhnologi untuk mengekspresikan perlawanan 
mereka. Ekspresi tersebut anatara lain mereka representasikan melalui meme, pelesetan kata dan lain sebagainya. Dengan baik Yusar kemudian menampilkan berbagai meme dan plesetan kata serta maknanya dalam artikelnya yang cukup panjang.

Tulisan terakhir ditulisn oleh Darmairal Rahmad, dosen sosiologi STKIP PGRI Sumatera Barat. Rahmad menulis integrasi dan interaksi anak muda rantau (kasus mahasiswa) di kawasan kost-kostan kota Padang. Dengan mengambil setting di kawasan Air Tawar Barat, Rahmad menemukan berbagai model dan tipologi interaksi dan ientegrasi anak muda dengan masyarakat di sekitarnya berdasarkan empat pola. Yang menarik dari tulisan Rahmad selain data yang kaya adalah pola penyajian data kualitatif dalam bentuk matrik probabilitas. Sebuah pola yang unik dalam penyajian tulisan kualitatif secara dalam bentuk matrik. Bisa jadi, ini akan menjadi model baru dalam metode penelitian yang kini sedang berkembang, yaitu mixed method.

Demikianlah para penulis telah menymbangkan buah fikiran mereka dalam edisi ini yang tentu saja dapat dibaca secara lebih mendalam pada setiap judul tulisan. Redaksi hanya mengantarkan pembaca pada kulit dari apa yang ditulis oleh para penulisn. Untuk lebih mendalam pada bagian isi, redaksi mengucapkan selamat membaca.

Redaksi 



\section{DAFTAR ISI}

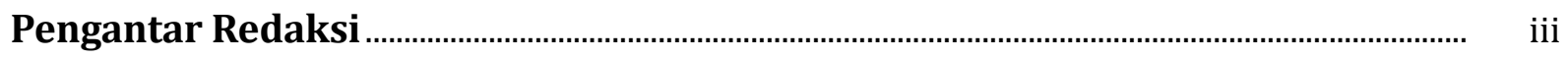

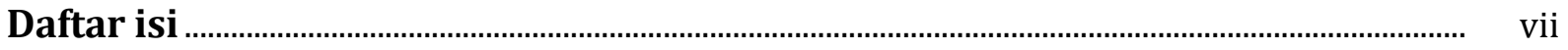

Seni Tradisi, Jatidiri dan Strategi Kebudayaan

Heddy Shri Ahimsa-Putra

Sejarah dan Nilai Songket Pandai Sikek

Silvia Devi

Budaya dalam Lintasan Sejarah: Booming Nonton Bioskop di Padang Tempo Dulu

Meri Erawati.

Paradoksal Gaya Sosial Global; Kajian Budaya dalam Memahami Kesadaran Kolektif di Tengah Booming Batu Akik

Silfia Hanani.

Gaya Kehidupan Malam Remaja di Kota Padang; Suatu Kajian Subkultur di Tempat Hiburan Malam Kota Padang

Faishal Yasin.

Perlawanan Kaum Muda terhadap Hegemoni Radikalisme Agama dalam Bentuk-Bentuk Budaya Populer

Yusar

Gaya Interaksi \& Integrasi Sosial Anak Muda Rantau: Kasus Mahasiswa Kost di Air Tawar Barat, Kota Padang

Darmairal Rahmad.

Profil Penulis 


\title{
PARADOKSAL GAYA SOSIAL GLOBAL; Kajian Budaya dalam Memahami Kesadaran Kolektif di Tengah Booming Batu Akik
}

\author{
Silfia Hanani \\ silfia_hanani@yahoo.com \\ Dosen Sosiologi, Institut Agama Islam Negeri Bukittinggi \\ 一非-
}

\begin{abstract}
Batu akik is a stone that is honed and polished, then show the beauty with a stunning artistic image. The beauty of it is basically what makes it become the preferred batu akik, the reputedly by the market so that it becomes a famous batu akik. The famous look of the ways to use it and ways to express it, so that the batu akik changing the collective consciousness of not stylish batu akik into entering that it style. The market has the potential to change the style of gemstone collectivity that, until the batu akik collectivity was defeated attention to other issues. However, behind it there is a need to be interpreted when the collectivity there, which each make interpretation batu akik with context locality and mystical, such as those used to interpret it. So, a collective consciousness with temporary style with locality and mystical, as a sign of Indonesian people are still familiar with mysticism in culture. This paper will describe the culture that emerged as a result of the rise of batu akik in the global era.
\end{abstract}

Key Word: Batu Akik, Globalization, Collective Consceusnes

Batu akik, merupakan batu yang diasah dan dihaluskan kemudian memperlihatkan keindahan dengan citra seni yang memukau. Keindahan itu pada dasarnya yang menjadikan batu akik itu menjadi disukai kemudian direputasikan oleh pasar sehingga batu akik itu menjadi booming. Keboomingan itu terlihat dari cara-cara menggunakannya dan cara-cara mengekspresikannya sehingga batu akik merubah kesadaran kolektifdari tidak bergaya batu akik menjadi memasukigaya batu akik. Pasar sangat berpotensi merubah kolektifitas gaya berakik itu, hingga kolektifitas berbatu akik itu mengalahkan perhatian terhadap isu-isu yang lainnya. Namun, di balik itu ada yang perlu dimaknai ketika keolektifitas itu ada, yakni masing-masing membuat interpretasi batu akik dengan kontek lokalitas dan mistis, seperti orang-orang dulu memaknainya. Jadilah, sebuah kesadaran kolektifdengan gaya temporer dengan lokalitas dan mistis, sebagai tanda orang Indonesia masih saja akrab dengan mistisime dalam budayanya. Tulisan ini akan menguraikan tentang budaya-budaya yang muncul akibat boomingnya batu akik tersebut di tengah genderang global yang modernis

Kata Kunci: Batu Akik, Globalisasi, Kesadaran Kolektif 


\section{PENDAHULUAN}

Hampir dua tahun belakangan ini manusia jagat dihebohkan oleh perubahan gaya global berbatu akik. Termasuk di Indonesia, batu akik menjadi booming yang mengalahkan beragam isu yang terjadi, bahkan dimanamana muncul pasar dadakan menjual batu dan pengasahnya. Di sudut-sudut kampung pun dengan mudah bisa ditemukan pengasah batu akik. Pencinta batu akik pun setiap hari diprediksikan bertambah dari setiap lapisan masyarakat, mulai dari lapisan bawah sampai atas. Demam batu akik terlihat di mana-mana menjadi fenomena yang disebut dalam istilah finasial psikologis menjadi irrational exuberance dimana orang beramairamai atau berbondong-bondong membeli batu akik karena dorongan emosi kolektif. Dalam hal ini ada suatu dimensi manusia yang terjajah yang membangun jarak antara pemikiran dan tindakan logis, sehingga tersebarangnya manusia dari istilah cagita ergo sum (Sutrisno\&Putranto, 2005:361)

Batu akik menjadi pembius gaya kolektif bagi masyarakat hingga ruangan dan waktu manusia selalu dipadati oleh pembicaraan dan materi batu akik itu. Akian (istilah yang sengaja diciptakan untuk pencipta batu akik untuk kepentingan penulisan) mengejar dan berburu batu akik dengan beragam interpretasi dan prediksi dari sebuah batu akik. Bermacam-macam interpretasi dan prediksi dikembangkan hingga batu mungil yang siap diasah dan dihaluskan itu menjadikan pencintanya tergila-gila. Tidak hanya sampai pada prediksi dan kecintaan itu, bahkan batu akik ini menjadi sebuah gaya global desa kota yang membius. Hal ini minimal dapat dilihat dari gaya jemari yang dihiasi batu akik tersebut. Tidak hanya dapat dilihat di jemari laki-laki tetapi juga kalangan perempuan.
Berakik menjadi gaya hidup yang terbius oleh emosional kegilaan kolektif yang disengaja atau tidak oleh dunia pasar atau kepentingan. Kenyataannya adalah berakik telah membuat pesona baru dalam gaya hidup dari semua kalangan. Menariknya adalah, mencermati sebuah gaya hidup yang didesain dengan kolektifitas emosional yang merata. Dimana berakik itu tidak hanya melanda kelas-kelas tertentu tetapi merata ke semua golongan, malahan anak-anak pun terbius oleh gaya hidup berakik tersebut, hingga jemari manusia ditemukan terlilit oleh cincin berpermata akik tersebut.

Terlepas daripada mahal atau murah harganya, namun gaya bercincin pakai permata akik tersebut menjadi gaya hidup yang merekontruksi budaya kekinian, sebelumnya yang bercincin seperti itu terkenal orangorang berisi ilmu "hitam" atau duku-dukun. Di akiknya itu diyakini ada magis dan mantagi atau kekuatan supratarul, orang takut dengan mantagi atau magisnya itu. Dipercayai bisa dipergunakan untuk kepentingan-kepentingan tertentu. Pada masa itu, kalau orang memakai cincin pakai batu akik dianggap orang berisi atau dukun yang memiliki banyak simpanan mistis, kegunaannya bukan untuk gaya tetapi ada sesuatu kemagisan. Simbolisasi batu akik seperti itu juga tidak luntur sampai sekarang, masih ada yang mengamalkannya dengan supranatural seperti itu.

Namun seiring dengan perkembangan dan masuknya batu akik ke dunia pasar, kontribusi batu akik meluas menjadi mode dan gaya. Menjadi prestise tersendiri bagi kalangan pemakainya. Batu akik memasuki varian harga yang sangat variatif. Variasi harga inilah yang menjadikan batu akik menjadi sebuah gaya konsumerisme yang menentukan level ekonomis seseorang. Semakin tinggi 
level ekonomi seseorang maka semakin bisa ditebak harga batu akik yang dimilikinya. Ada simbol prestise juga dalam kepemilikian batu akik itu, pandangan ini yang tidak bisa ditukarbalikkan dalam gaya berbatu akik. Orang-orang tertentulah yang bisa mencapai pemakaian akik yang berharga mahal walaupun akik itu membooming adanya.

Kondisi batuk akik yang membooming menjadi gaya hidup ini apakah ini yang disebut dengan budaya populer seperti yang diperkenalkan oleh Storey (Barkes, 1999: 62) atau budaya era baru seperti diungkap oleh Hall dan Jaques (Barker, 1999: 136). Boleh jadi juga fenomena gaya ini disebut oleh Capra (2004:7) dengan penaykit-penyakit kebudayaan. Mungkin jadi juga kondisi ini disebut oleh Khaldun dengan siklus kebudayaan, gaya hidup yang berulang yang tertata oleh masa dan zamannya. Semuanya dijelaskan oleh Taleb (2009) dengan The Black Swan peristiwa yang tak terduga.

\section{METODOLOGI}

Tulisan ini, pada dasarnya merekam sebuah kebudayaan populer yang booming diproduksi secara komersialisme, sehingga konsumerismenya bercampur dalam sebuah gaya hidup yang masuk ke dalam semua level sosial, ekonomi dan seterusnya. Secara kasat mata nampak dan diperbicangkan oleh banyak orang namun dalam kerumunan, seperti di tengah pasar, di warung-warung kopi bahkan sampai ke ruangan akademik yang didiskusikan sekilas lalu tanpa mendalam hanya sebatas hobi oleh akademik itu. Oleh sebab itu, dari keadaan luar bisa dipotret dengan jelas adalah tentang gaya yang menyebar atau booming, nampak terpraktikkan oleh akian sehingga menjadi fenomena yang bisa banyak diceritakan.
Sesuai dengan kepentingan untuk pembahasan ini booming itu menjadi fakta dan datanya. Kondisi boomingsitas tersebut bisa dipotret melalui pengamatan, penglihatan dan bahkan mendengarkan diskusi-diskusi di antara pencinta akik di pasar, tempat pengasah akik, tempat penjual batu bahkan di diskusi informal akademik ketika pencintanya berdiskusi sebuah kecanduan dan hobi. Pengamatan dilakukan di tempat-tempat penjualan batu akik di pasar-pasar dadakan, dimana para pencinta batu akik berkompromi dan mempresentasikan berbagai interpretasi batu akik itu. Dari pasar-pasar dadakan itu pula telihat bagaimana seseorang berprilaku mengikuti gaya berbatu akik tersebut. Beberapa pengamatan yang dilakukan di beberapa pasar dadakan adalah di Bukittinggi dan Batusangkar. Tentu yang sangat penting adalah dalam menganalisis gaya hidup akibat booming itu literatur-literatur yang terkait dengan kajian culture studies dan kajian gaya hidup global, tanpa menghiraukan kajian yang esensial tentang batu akik itu sendiri.

\section{PARADOKS BATU AKIK}

Dalam proses kelahiran Anthropologi kita masih ingat dengan pencatatan-pencatatan yang dilakukan oleh para penjelajah dan pengembang agama ketika melakukan perjalanan ke berbagai kawasan. Pencatatan itu, memotret berbagai budaya dan praktik kehidupan dalam sebuah masyarakat. Diantaranya memotret teknologi dan cara hidup dan implikasinya pada gaya hidup sebuah suku atau masyarakat. Dari catatan-catatan itu, ternyata ada budaya yang terulang, ada budaya lama muncul kembali dan ada gaya hidup yang melengkung ke siklus semula, sekalipun sistem ekonomi, politik dan sosial berbeda. 
Tidak bisa diabaikan adalah mengenai penggalan sejarah zaman batu dalam kebudayaan manusia. Manusia menggunakan tekhnologi batu dalam memudahkan kehidupannya, sehingga batu diolah dalam berbagai bentuk sehingga memudahkan manusia menata kehidupannya. Seiring dengan perkembangan, pemaknaan batu itu sudah berbeda dan pengolahannya pun berbeda. Sekarang batu itu dibuat menjadi bahagian dari sebuah art atau seni yang bisa membius manusia yang dibantu oleh marketing pasar yang begitu heboh. Dimana keberadaanya tidak hanya lagi berada di telasetelase mall yang mewah tetapi sudah ada di emperan-emperan dan setiap sudut kampung menjualnya.

Sekalipun kondisi seperti itu bisa disebut sebagai sebuah siklus dalam kacamata Khaldun, tetapi tidak bisa dipungkiri adalah kondisi yang terjadi sekarang adalah komodifikasi tetap saja ada khazanah yang berbeda. Apalagi dalam konteks sekarang, komodifikasi itu dipengaruhi dengan kuat oleh pasar, sehingga tidak ada budaya yang otentik namun ada aura dan nuansa nostalgia romantismenya, sehubungan itu disinilah gaya hidup itu bermain dan memunculkan diri.

Gaya hidup menjadi terpusat dalam satu model, dimana pasar sangat berperan penting dalam membentuknya. Pasar menjadi pembius gaya hidup yang mengarahkan orang tunduk pada komersialisme pasar itu sendiri. Keasadaran dan dikalahkan oleh emosional yang diputar oleh pasar. Oleh sebab itu tidak heran Naisbitt mengatakan sesungguhnya pusaran golal sebenarnya adalah dimana "arena" subjektifitas manusi terputar balik, bisa kembali pada masa lalu atau bisa kembali menjadi kekanak-kanakan dan seterusnya karena helaan kepeningan pasar tadi yang membuatnya terputar-putar itu.
Jadi sulit ditebak kemunculan gaya hidup global itu, karena pusarannya adalah pasar. Pasar yang membentuknya dan mengarahkannya, sehingga kemunculan gaya hidup dalam pusaran global penuh dengan kejutan-kejutan dalam istilah Nassim Nicholas Taleb disebutnya dengan the Balck Swan. Artinya, yang tidak kita duga itulah yang terjadi. Itu pula kemunculan batu akik yang didesain oleh pasar trendnya kemudian menduniakan gaya hidup berbatu akik.

Gaya batu akik itu disebut dengan sebuah gaya paradoksal gaya yang tidak diduga-duga di tengah-tengah manusia global modern haus tekhnologi, kemudian berbalik arah menjadi sebuah gaya "kampungan" tetapi eleganitasnya memukau. Kesadaran-kesadaran diformalitaskan menjadi satu bentuk. Pasar mengarahkan pada era baru, dimana kondisi-kondisi sosial berubah dengan cepat. Pembicaraan, agenda-agenda manusia selalu saja diwarnai dengan hal-hal yang baru muncul itu. Kadang-kadang kondisi itu mendesak sistem formalitas untuk menatanya, seperti halnya sekarang ini ada daerah yang sudah mewacanakan untuk membentuk Peraturan Daerah Tentang Batu Akik ini, seperti di Rokan Hulu Provinsi Riau, dimana pemerintah daerahnya berkeinginan merancang sebuah peraturan daerah khusus untuk batu akik. Rancangan Perda selain bertujuan untuk melindungi perajin batu akik juga bertujuan untuk melindungi alam dari kerusakan akibat eksplorasi batu yang dilakukan oleh pencinta batu akik Selama ini batu-batu itu tersebar di dasar sungai, tanah dan sebagainya sebagai kekayaan alam tetapi karena pasar mempopulerkannya dan kemudian booming batu akik mendesain kehidupan manusia, terjadi penggalian yang luar biasa dan merusak lingkungan. Kondisi seperti ini yang disebut 
dengan global paradoks ketika masyarakat dunia mempopulerkan keselamatan lingkungan kemunculan perusaknya oleh desakan-desakan kepentingan manusia berlangsung dengan secara brutal pula.

Dalam konteks ini, booming batu akik melahirkan fenomena global paradok, setidaknya dapat dilihat dari sikap terhadap eksplorasi dan eksploitasi alam, dimana di tengah-tengah masyarakat modern hiruk pikuk dengan penyemalatan alam, namun satu sisi akibat konsekuensi style kehidupan terjadi tanpa sadar eksploitasi alam itu. Di sini kita membenarkan global paradok yang di perkenalkan oleh Naisbitt pada awal tahun 2000. "Dimana di tengah penyelamatan derasnya penyelamatan alam secara global, namun ada pula kuasa yang kuat untuk merusaknya, di tengah orangorang modern bergaya hodonesime, ada pula orang modern kembali menggilakan dirinya bertradisi kelamaan dan seterusnya". Intinya adalah globalisasi dipadati oleh kontraversikontraversi yang dalam berbagai aspek yang disebut dengan global paradoks (Naisbitt, 1994)

Keboomingan batu akik ini dapat pula dibaca sebagai sebuah dinamika global paradok itu, dimana semakin melaju gaya hidup modernis semakin kuat pula gaya tradisionalitas direpresentasikan. Terlihat ada kebangkita-kebangkitan tradisionalitas untuk memperkuat dan melengkapi modernitas. Akhirnya ada keyakinan bahwa siklus sejarah di dunia ternyata terlihat berulang, atau disebut dengan melingkar, sebagaimana dikemukakan oleh Sorokin yang hidup dalam rentang waktu 1889-1968. Sorokin melihat $\mathrm{d}$ dalam kondisi berulang itu ada mentalitas budaya yang membangun masing-masingnya. Dalam mentalitas budaya itu ada budaya- budaya yang dipertahankan, atau diingat kembali atau dipertahankan atau dihadirkan kembali. Untuk menjelaskan keberadaan batu akik dalam kondisi kekinian ini, perlu dilihat kembali mentalitas budaya yang dikemukakan oleh Sorokin ini. Sorokin menyebutkan ada tiga mentalitas yang selalu berulang dalam sejarah kebudayaan manusia, yaitu pertama kebudayaan ideasional, yang pada dasarnya merupakan sebuah terminasi daripada daya fikir yang mengkaitkan pada siklus kehidupan dan kepentingan yang transenden, ada daya ikat yang mengukuhkan pada kekuatankekuatan di luar diri manusia. Kedua disebutnya kebudayaan inderawi, menyatakan kebudayaan adanya kebudayaan yang duniawiah, disinilah berlaku segala interpretasi terhadap yang dilihat oleh inderawi itu. Sedangkan yang ketiga disebutnya kebudayaan campuran antara ideasional dan inderawi. Namun, Sorokin selalu meramalkan ada keberbalikan akhir dari periode inderawi akan kembali pada kelahiran tahap mentalitas ideasional (Jhonson, 1989:99-102). Pemikiran Sorokin ini agaknya, juga mendasari paradoksal yang terjadi dalam tuntutan global. Ketika budaya melaju ke dalam bentuk modernitas kemudian menguat pula budaya tradisionalitas. Ketika orang sudah menyamankan dirinya dalam gaya kehidupan global modernis, kemudian gaya tradisionalitas yang ideasional menguat pula kembali.

Ada beberapa paradoksal gaya hidup dan sosial yang terbentuk ketika melihat boomingnya batu akik itu sekarang ini, diantaranya paradoksal itu adalah:

\section{KOEKSISTENSI GAYA KOTA \& DESA}

Ketika mengamati booming batu akik sekarang ini, semakin nyata oleh kita bahwa 
globalisasi yang dikuasai oleh pasar itu telah mengungkai batasan-batasan desa kota, batas gaya hidup, batas kesadaran dan seterusnya. Benang merah batas gaya hidup dan sosial itu kabur dan samar, karena orang desa dan kota sama-sama menjadi korban konsumerisme akik yang digadang-gadangkan oleh pasar. Kasadaran kolektif akan batu akik sudah didesain oleh pasar, sehingga setidaknya terlihat jemari-jemari bercincin permata akik dengan mudah ditemukan.

Kesadaran kolektif yang tergiring pasar ini, tidak lagi membedakan gaya hidup kota dan desa, sama-sama tergilas oleh satu arahan pasar. Akibat gilasan pasar itu, orang tidak mempertimbangkan makna batu akik seperti masa lalu yang penuh dengan magis, tetapi pertimbangan itu bergeser pada mode dan gaya. Ketika itu mode dan gaya itu yang menentukan adalah eleganitas dan kemahalan harga. Dari sisi ini yang tidak bisa dipungkiri, harga menjadi penanda dan pembeda pemakainya, karena kesadaran kolektif itu digiring oleh pasar maka alat penandanya adalah harga. Harga implikasinya adalah prestise dan kelas.

Ketika harga menjadi penanda, konsekuensi logisnya adalah prestise dan cara pandang terhadap sebuah material sehingga batu akik menjadi penanda yang membedakan nilai harga ketika dipakai oleh seseorang. Penyatuan gaya desa kota itu ada tetapi tetap ada perbedaan yang dikungkung oleh harga nilai dari sebuah batu akik. Namun, dalam konteks memahami fenomena booming batu akik sekarang adalah bius trend yang dihalau oleh pasar dalam kegilaan kolektif, dimana lintas-lintas batas desa dan kota terabaikan karena imajinasi orang kota dan desa sudah diperangkap oleh batu akik.

Disadari atau tidak telah melahirkan diffusi gaya hidup yang melampaui batas- batas sosial budaya kota dan desa. Ruang dan waktu masyarakat desa dan kota selalu saja tersedia dan bahkan selalu dibangun untuk membicarakan masalah batu akik tersebut sehingga manipulasi-manipulasi gaya pun muncul di tengah-tengah pembicaraan itu. Manipulasi itu setidaknya terlihat dari bermacam-macam interpretasi seni dari batu tersebut, tidak hanya lagi magis dan kekuatan supranatural seperti masa batu akik menjadi trend cincin yang dipakai oleh seorang dukun di pedesaan.

Batu akik tidak lagi dimaknai sebagai sebuah produk nilai tradisional, tetapi menjadi produk budaya tradisional desa yang direkontruksi dalam kemodernitasan, dari produk desa yang dipercayai sebagai komponen magis bagi orang-orang desa ketika berkaitan dengan proses pengobatan atau kerja dukun, kini menjadi produk kota yang bernilai ekonomis. Di sinilah, diyakini tawaran budaya batu akik, dimana ketika orang-orang kota dibaluti kosmopilit gaya, namun kekuatan tradisionalitas desa dengan konstelasi batu akik menguat pula dan menggiring kesadaran kolektif kepada "kebatuan" dengan berbagai interpretasi yang biasa dikembangkan dalam masyarakat tradisional. Dimensi koeksistensi gaya kota dan desa yang ditawarkan oleh batu akik, bisa dilihat dari beberapa kondisi yang terjadi, seperti terlihat pada tabel di bawah ini:

Tabel 1

Koeksistensi Gaya Kota dan Desa

\begin{tabular}{|c|c|c|}
\hline \multirow{2}{*}{$\begin{array}{l}\text { Aspek dan } \\
\text { Dimensi }\end{array}$} & \multicolumn{2}{|c|}{ Koeksitensi Style } \\
\hline & Kota & Desa \\
\hline Pasar & Modern & Tradisional \\
\hline Interpertasi & Logis & Magis \\
\hline Representasi & Berkelas & Sederhana \\
\hline
\end{tabular}

Dimensi itu dapat dilihat dari kehingarbingaran batu akik sekarang ini, dua kekuatan tumbuh secara bersama di konstelasi kehidupan sosial booming batu akik, dimana 
di tengah menggelindingnya pasar global yang modernis kekotaan, ternayata batu akik mengglobal pula dengan gaya tradisionalnya, tumbuh dengan kaki lima di pinggir-pinggir jalan dan emper-emperan toko tetapi ramai dikunjungi oleh orang. Begitu juga dengan interpretasi, gaya-gaya orang modernis yang anti interpetasi magis irrasional karena semua diukur dengan kelogisan, kini kembali membangun irrasional bertendensi magis tersebut, sehingga batu akik disebut-sebut bisa digunakan untuk kepentingan pengobatan, penolong penguatan batin dan seterusnya. Sedangkan representasi dari keboomingan batu akik adalah adanya perpaduan gaya berkelas dan sederhana.

Di samping itu kebomingan batu akik juga memperlihatkan adanya integritas sosial yang membangun kelompok-kelompok sesama pencinta, saat ini sudah muncul di beberapa daerah kekompok pencinta batu akik dengan kegiatan-kegiatan ekonomi dan solidaritas. Artinya, globalisasi yang memperlihatkan kultur sosial individual ternyata keboomingan batu akik kembali menyusun kekuatan kelompok sesama pencinta batu akik itu.

Menurut Durkheim, kolektivitas sosial atau solidaritas sosial itu tumbuh dalam masyarakat pedesaan, masyarakat yang hidup dalam dinamika sosial sederhana dan bersolidaritas mekanik (Johnson, 1989: 188). Namun, kolektivitas itu bisa dikuatkan kembali di tengah-tengah kemodernan masyarakat kota melalui organisasi-organisasi yang dibangun sesuai dengan tujuan dan kepentingan para pengikutnya. Batu akik bisa kembali mempertemukan masyarakat global dengan satu kesadaran kolektif yang ditawarkan melalui batu akik.

\section{MENGUBAH MAKNA MAGISITAS KE GAYA GLOBAL}

Melihat perkembangan fenomena yang terjadi dari booming batu akik adalah, sebuah perubahan makna magisitas supranatural ke gaya global. Semula tanpa diikat oleh pasar, hanya diikat oleh pengalaman bathin dan kebutuhan magisitas yang dapat dianggap menjadi "alat" sehingga orang yang memakai cincin dengan batu akik itu hanya orangorang tertentu, seperti bomoh atau dukun. Di batu akik yang menjadi permata cincin yang dipakainya itu terjadi berbagai interpretasi, malahan ada yang menginterpretasikan batu akik yang menjadi permata di cincin tersebut bisa menjadi alat penangkal kejahatan, bahkan bisa mengebalkan tubuh dan sebagainya.

Sekarang makna itu telah bergeser kepada gaya global, gaya yang sudah tidak terbatas oleh satu nilai magisitas yang memiliki supranatural tetapi gaya hidup yang membuat kesamaan di belahan dunia, yakni kesamaan atas prinsip art atau seni yang nilainya ditentukan oleh harga jualnya. Oleh sebab itu, pemakaian cincin berbatu akik permatanya bukan lagi orang-orang berpenampilan serem seperti seorang dukun.

Di sinilah kita meyakini ungkapan lama daripada Naisbitt dalam megatrend dunia bahwa pada era global ini ada kebangkitan fashion atau atribut-atribut jasmaniah yang memukau. Salah satunya adalah trend berbatu akik sebagai permata batu cincin atau yang lainnya. Kebangkitan fashion ini pada dasarnya adalah buah dari kegilaan pasar yang menjadi mesin indutri menghalau keadaran kolektif ke arah yang sama.

Pasar sengaja digerakkan untuk mempopulerkan batu akik, ketika dipopulerkan oleh pasar itu tidak ada simbolis magisitas makna 
yang digambarkan atau diinterpretasikan tetapi yang ada adalah nilai pasar yang sangat ditentukan oleh art dalam konteks global. Peralihan fungsi pun terjadi, semula fungsinya banyak direpresentasikan sebagai kekuatan magis namun sekarang fungsinya terkait dengan nilai investasi dan barang berharga.

Demikianlah pada dasarnya pasar itu menginginkan sebuah kondisi dimana kondisi itu tidak hanya sebatas materialisme tetapi adalah mewujudkan materialisme itu menjadi barang bernilai uang. Akhirnya, tadi hanya sebagai korban kolektifitas kemudian kini berkembang menjadi gaya hidup. Kemudian industri-indutri untuk pemasok batu akik yang bernilai seni itu menjamur tumbuh bagaikan cendawan di musim hujan. Seperti munculnya pengasah atau pengrajin batu akik dimana-mana sehingga mempermudah untuk menghasilkan batu akik yang bernilai seni itu. Semua perangkat-perangkat pendukung itu adalah sistem yang mengubah sebuah keinginan supaya manusia menjadi konsumen dari batu akik. Setelah menjadi konsumen, muncul beragam image namun tetap dalam kerangka mengubah kesadaran kolektif untuk mendandankan jemarinya dengan permata yang berasal dari batu akik.

Ada yang mengatakan dengan adanya batu melahirkan kharisma tersendiri, membuat orang segan orang-orang yang menaruh batu akik di badannya. Oleh sebab itu tidak heran ada orang yang memakai cincin berbatu akik lebih dari satu di jemarinya dengan tujuan untuk menguatkan kharisma dirinya. Kepercayaan seperti itu hampir mengkolektif dalam pikiran pencintanya. Ada keyakinan kolektivit memakai batu akik menambah aura dan kharismanya. Bahkan lebih dari itu, malahan ada yang meyakini keberadaan sebuah batu akik di badannya bisa memperlancar karir dan jabatan.
Jadi dalam kondisi kemodernan sekarang kelogisan bisa ditumbangkan oleh magisitas. Batu akik, ternyata juga mengglobalkan magis dalam masyarakat modern dan sekaligus mematahkan nalar dan logisitas pencinta batu akik.

Ada beberapa asusmsi magis yang dibangun dalam keboomingan batu akik sekarang ini, magis itu dipercayai oleh lintas usia, lintas tradisi dan lintas pekerjaan, diantaranya adalah:

Tabel 2.

Nama dan Magisitas Batu Akik

\begin{tabular}{|c|c|c|}
\hline No & Nama Batu Akik & Magis Yang Ditawarkan \\
\hline 1 & $\begin{array}{l}\text { Kubus Benteng } \\
\text { Prahara }\end{array}$ & $\begin{array}{l}\text { Terhindar dari segala bencana dan } \\
\text { juga untuk menmbah kewibawaan }\end{array}$ \\
\hline 2 & $\begin{array}{l}\text { Mustika macan } \\
\text { putih dan sisik } \\
\text { naga }\end{array}$ & $\begin{array}{l}\text { Menambah kekuatan dan keberanian, } \\
\text { membuat pribadi seseorang disukai }\end{array}$ \\
\hline 3 & Tapak jalak & $\begin{array}{l}\text { Menambah kewibawaan dan } \\
\text { penangkal santet }\end{array}$ \\
\hline 4 & Junjung derajat & $\begin{array}{l}\text { Mengangkat derajat seseorang, } \\
\text { mengangkat darejat perekonomian, } \\
\text { status sosial }\end{array}$ \\
\hline 5 & Pancawarna & $\begin{array}{l}\text { Memancarkan kharisma dan } \\
\text { melindungi dari kejahatan }\end{array}$ \\
\hline 6 & Black jade Aceh & $\begin{array}{l}\text { Digunakan terapi untuk berbagai } \\
\text { penyakit }\end{array}$ \\
\hline 7 & $\begin{array}{l}\text { Bacan Jahanam } \\
\text { Maluku }\end{array}$ & Untuk menyembuhkan penyakit \\
\hline 8 & Merah delima & Pembantu pencapaian kejayaan \\
\hline 9 & Kecabung & $\begin{array}{l}\text { Mempermudah membangun relasi } \\
\text { dan perkawanan }\end{array}$ \\
\hline 10 & Amber & $\begin{array}{l}\text { Membantu memancarkan kharisma } \\
\text { dan menimbulkan daya tarik yang } \\
\text { luar biasa }\end{array}$ \\
\hline 11 & Intan & $\begin{array}{l}\text { Menawarkan ketenangan dan } \\
\text { kenyamanan }\end{array}$ \\
\hline 12 & Onix hitam & Melindungi bisnis \\
\hline 13 & Zamrut & $\begin{array}{l}\text { Menawarkan penyejuk bathin ketika } \\
\text { kesulitan }\end{array}$ \\
\hline 14 & Combong & Penangkal santet \\
\hline 15 & Hakikat & Untuk penunduk musuh \\
\hline 16 & Serai & $\begin{array}{l}\text { Pengobat dari penyakit mistis serta } \\
\text { pendatang rezki secara tiba-tiba }\end{array}$ \\
\hline 17 & Badar besi & $\begin{array}{l}\text { Penangkal dari sentuhan senjata } \\
\text { tajam }\end{array}$ \\
\hline 18 & Mata kucing & $\begin{array}{l}\text { Memiliki aura penarik, membuat } \\
\text { musuh takut dan takluk, penghindar } \\
\text { sihir }\end{array}$ \\
\hline 19 & Mata harimau & Membantu dalam kepercayaan diri \\
\hline 20 & Nilam & Menjernihkan fikiran \\
\hline 21 & Jarum emas & Pelaku bisnis \\
\hline
\end{tabular}

Sumber: disimpulkan dari beberapa wawancara dan beberapa situs yang membahas tentang batu akik 
Beberapa yang ditemukan dari nama dan khasiat batu akik tersebut, nampak dengan jelas bahwa perkembangan interpretasi magisitas dari batu akik itu sudah menyebar luas dan magisitas ini pula yang membuat daya tarik batu akik dicari dan dipakai oleh seseorang. Menurut informasi dari sebuah situs batu akik sudah digunakan semenjak 20.000 tahu Sebelu Masehi yang pada mulanya digunakan untuk perhiasan (http://boombastis.com/2015/02/24/faktamitos-batu-akik/). Kemudian berkembang fungsinya sebagai pemilik kekuatan magis, interpretasi kekuatan magis itu yang juga ikut memboomingkan batu akik di tengah-tengah modernitas global sekarang ini.

Keboomingan batu akik saat ini ternyata telah mendesain pencinta dan pemakainya melangkah dengan interpretasi-interpretasi magis tadi. Seni yang ditampilkan di tubuh tidak hanya semata kekuatan seni tetapi ada makna magis yang dipercayai sebagai penyertanya. Bagi kalangan yang fanatik adanya kekuatan magis di dalam batu akik itu, menyebutkan bahwa untuk mendapatkan batu tersebut tidak mudah dan tidak bisa dijual di pasar-pasar bebas dan tidak sembarang orang bisa mendapatkannya.

Orang-orang tertentu yang bisa mendapatkan batu berkekuatan magis itu, diperoleh pun tidak di tempat sembarangan tempat. Biasanya diperoleh di tempat-tempat tersembunyi, misalnya di lubuk satu di sebuah sungai, atau di rimba yang terkenal dengan penghuninya. Jadi bagi kalangan yang fanatik ini, batu akik yang dijual di pasar secara bebas itu hanya sebagai seni untuk menambah aksesoris bagi pemakainya dan sulit dipercaya keberadaan magis ada di dalamnya.

Untuk mendapatkan batu akik yang dipercaya memiliki kekuatan magis itu, kadang-kadang ada petunjuk yang diterima oleh seseorang, misalnya melalui mimpi atau petunjuk dari orang-orang suci termauk juga dari seorang dukun yang terkenal dengan ilmu bathinnya. Atas petunjuk-petunjuk itu, diperoleh batu tersebut melalui ritual-ritual yang diperkenankan, bahkan sampai dengan bertapa dalam waktu yang ditentukan untuk bisa mengambilnya.

Kondisi cara mendapatkan batu akik yang seperti itu membuat pemakai batu akik di masa lalu hanya oleh kalangan-kalangan tertentu saja, seperti dukun atau bomoh bukan dipakai oleh sembarang orang seperti sekarang ini. Itu pula di masa lalu masyarakat meyakini, orang-orang pemakai batu akik tersebut orang yang ditakuti karena adanya kesaktiannya yang dibantu oleh batu akik.

Pandangan batu akik kekinian, interpretasi magisnya telah dibuat secara terbuka, tidak dengan cara ritualistik seperti orang dahulu. Magis yang melekat itu bahkan sudah diumumkan secara terangterangan, seperti terlihat dari nama-nama yang dipopulerkan di atas. Pada hal menurut kelompok konservatif tidak mudah membuat interpretasi dan nama dari sebuah batu akik yang memiliki magis itu. Harus terlebih dahulu melalui ritualitas dan memenuhi syarat-syarat yang dibutuhkan sesuai dengan keyakinan atau petunjuk-petunjuk kebiasaan.

Dari perkembangan yang terjadi yang terpenting dimaknai adalah bahwa batu akik dalam booming global ini, pengemar dan pencintanya kembali menyisiri magis sebagai kekuatan penyerta dalam kehidupannya. Logisitas telah dipatahkan oleh magisitas yang dibawa oleh batu akik tersebut. Sehubungan dengan ini, analisis siklus budaya Ibnu Khaldun diterima, dimana sejarah dan budaya itu menyisiri kembali jalan lamanya, orang-orang 
modern yang sudah lama bergaya modernis dan mengemukakan logisitas dalam segala tindakan kini kembali ke gestur lamanya yang berbalut magis tersebut.

Di Indonesia dimana masyarakatnya menurut Mochtar Lubis memiliki ciri utamanya percaya tahayul (Marzali, 2005:124). Keberadaan magis di batu akik itu masih mendasar, masih diakui secara kolektif sehingga pengetahuan masyarakatnya tentang magis melekat di batu akik langgeng sampai sekarang, namun saja "marwah" kemagisannya tidak sama dalam pandangan konservatif. Dalam pandangan konservatif nilai magis itu sangat dijunjung dan diberi "prasayarat" tertentu, tidak bisa diperoleh dengan begitu saja, seperti di pasar bebas.

\section{MENGUBAH STANDARISASI UMUM MENUJU SPESIALISASI}

Ketika sesorang sudah masuk ke dalam emosio kolektif muncul fenomena menarik di kalangan pencinta atau peminat batu akik ini, dimana semakin seseorang masuk ke dalam kesadaran kolektif akik itu, maka orang itu akan menghilangkan kesadaran umumnya dan beralih pada kekhususan. Dimana semula hanya menjadi "konsumen" biasa karena ikut trend namun setelah mengenal trend akikan melanjutkan emosioalitasnya mencari kekhususan, atau spesialisasi makna dari batu akik. Makna itu bukan dalam konstelasi magis, tetapi keindahan dan citra aura seni yang dibawa oleh batu akik tersebut. Dalam konteks ini orang akan mendesaian kekhususan. Kekhususan itu bisa dicari dan diciptakan sesuai dengan kebutuhan sehingga memperlihatkan adanya perbedaan-perbedaan. Oleh sebab itu wajar saat sekarang terjadi perburuan batu akik sampai ke lembah-lembah, kemudian menginterpetasikan hasil temuannya itu dengan berbagai penafsiran seni, sehingga ada melekat pada temuan itu bentuk khusus dari yang lain dan sebagainya.

Pencinta batu akik tidak lagi terkosentrasi pada material akik, tetapi telah menciptakan nama-nama secara spesifik dan spesial dari batu itu sehingga berkembang berbagai nama dari batu akik. Pada nama-nama itu lahirlah spesifikasi lokalitas dan bahkan membawa kearifan lokal tersendiri ketika didekatkan dengan nama-nama lokal. Dengan demikian kesadaran kolektifitas telah terbelah menuju spesifikasi tadi. Batu akik berdasarkan nama lokalitas dan nama-nama yang dikonstruksi itu ternyata membawa konseksuansi tersendiri. Terutama konsekuensi harga dan kualitas. Konstruksi sepsifikasi ini menjadi penanda bagi batu akik atau menjadi identitas tersendiri, secara komersial pasar menjadikan harga batu akik berdasarkan klasifikasi ini tervariankan.

Di dalam konteks ini, terjadi perubahan dari standarisasi umum memaknai batu akik menjadi spesialisasi berdasarkan berbagai konstruksi. Batu akik akan disepesialisasikan berdasarkan nama-nama tempat ditemukan atau sesuai dengan motif yang melakat padanya. Berdasarkan spesialisasi ini terjadi beragam image mulai dari image kualitas dan interpretasi yang beragam. Implikasinya kepada harga dari batu akik itu menjadi berbeda-beda.

Di Sumatera Barat misalnya, dikenal dengan jenis spesial batu akik dari Sungai Dareh, dengan bentuk dan ciri kahs tersendiri. Identitas tersebut menunjukkan kepada semakin global sebuah material, maka semakin dicari identitas spesifik, sehingga keberadaan batu akik tidak hanya melekat material batu berwarna dan memiliki seni tetapi juga ditentukan oleh identitasnya secara spesifik. 
Identitas ini dibangun oleh simbolsimbol tersendiri yang menjadikan batu akik memiliki harga yang mahal. Dalam kondisi global simbol dan identitas itu menjadi penting dalam konteks global sekarang ini, sebab semakin global penawaran maka semakin menuntut kekhasan dari sebuah material dan semakin mahal nilai jualnya.

Standarisasi akan mengalami perubahan dari style umum kepada style yang khas dan memiliki identitas tersendiri. Hal ini dapat dilihat dari nama-nama yang diberikan pada batu akik sesuai dengan nilai seni dan interpretasi yang diberikan pada batu akik tersebut. Saat ini, nama-nama batu akik itu sudah beredar sesuai dengan spesifikasi dan identitasnya tersendiri. Dimana setiap batu akik, selalu punya nama, nama-nama itu menunjukkan harga dan nilai yang melekat padanya.

\section{INTEREAKSI LOKALITAS DENGAN PASAR}

Sebagaimana telah disebutkan bahwa spesifikasi batu akik salah satunya adalah dikaitkan dengan lokalitas batu akik itu ada atau ditemukan. Tidak jarang tempat penemuan-penemuan batu akik yang diminati itu menjadikan populer diberbincangkan oleh masyarakat pencinta, misalnya batu akik Sungai Dareh, Batu Akik Martapura dan seterusnya. Dimana nama-nama itu menjadi dikenal dan seakan-akan berinteraksi secara global di pasar.

Nama-nama lokalitas ini, menjadi penanda dari sebuah batu akik dan bahkan menjadi terkenal karena nama itu melekat pula pada nama salah satu batu akik. Tidak itu saja, bahkan perburuan batu akik pun menyebabkan adanya eksplorasi penjelajahan wilayah perbatuan yang sengaja diciptakan oleh pencinta batu akik. Jadi ada reputasi wilayah atau lokalitas dibangun oleh batu akik, dimana selama ini sebuah wilayah hanya tak dikenal menjadi terkenal karena adanya penemuan batu akik yang berkualitas.

Penemuan itu yang menjadikan adanya komoditi desa mengantarkan persentuhan desa kepada pasar termasuk pasar global. Semula desa yang tidak terakses oleh pasar, karena adanya penemuan-penemuan batu akik menjadikan desa atau suatu kawasan menjadi suatu yang sangat penting dalam perdagangan pasar, malahan menjadi terkenal secara global. Kondisi ini juga mempercepat terjadi proses global village yang dirancang dalam era global. Di samping itu dengan adanya nama-nama yang diberikan untuk batu akik sesuai dengan daerah penemuannya, maka interaksi lokalitas dengan pasar terbukti dengan jelas. Berikut di ada beberapa nama batu akik berdasarkan nama daerah penemuannya:

Tabel 3.

Nama-Nama Batu Akik Berdasarkan Nama Daerah Penemuannya di Sumatera Barat

\begin{tabular}{|c|l|l|}
\hline No & \multicolumn{1}{|c|}{$\begin{array}{c}\text { Nama Wilayah } \\
\text { Penemuan }\end{array}$} & \multicolumn{1}{c|}{ Nama Batu akik } \\
\hline 1 & Suliki & Lumuik Suliki \\
\hline 2 & Sungai Dareh & Lumuik Sungai Dareh \\
\hline 3 & Sungai Talang & Cimpago Madu \\
\hline 4 & Rao Pasaman & Pancar Lumut \\
\hline 5 & $\begin{array}{l}\text { Tanjung Ipuah Koto } \\
\text { Malintang Tanjung Raya }\end{array}$ & Lumuik Tanjuang Ipuah \\
\hline 6 & Pesisi Selatan & $\begin{array}{l}\text { Lumut tapan, lumut karang, } \\
\text { lumut limau manis }\end{array}$ \\
\hline 7 & $\begin{array}{l}\text { Sikucur, V Koto } \\
\text { Kampung Dalam }\end{array}$ & $\begin{array}{l}\text { Burai Lumuik, Burai Bulan, } \\
\text { Burai Ruyung, Burai Madu, Burai } \\
\text { Dalimo }\end{array}$ \\
\hline
\end{tabular}

Interaksi lokalitas ini, terkadang melahirkan berbagai kemungkinankemungkinan seperti adanya kebijakan untuk membuat peraturan daerah tentang batu akik. Munculnya wacana-wacana dibalik booming batu akik, tidak bisa dipungkiri bahwa batu akik bisa menjadi sarana komodifikasi identitas 
sebuah wilayah, karena melalui batu akik bisa menjadikan sebuah wilayah menjadi terkenal kemudian menjadikan perubahan-perubahan baik yang diinginkan maupun tidak diinginkan.

Dalam konteks ini, semakin diyakini tesis Ibn Khladun (2011:445) tentang dialek kota-desa dimana ada perantara yang bermain membangun dialek itu, bisa jadi dalam bentuk barang atau dalam bentuk kekuasaan atau sumber-sumber tertentu yang membuat saling ketergantungan. Dialektika ini, menjadikan adanya keterbukaan-keterbukaan yang membuat tidak ada batas wilayah, budaya dan sosial. Orang sama-sama digiring oleh pasar dengan meninggalkan kekuatan kulturalnya. Ketika dialektika itu berjalan terus maka ada kemungkinan ada yang hilang diantara dua kawasan itu, boleh jadi kehilangan nilainilai atau budaya itu sendiri karena dipaksa masuk ke dalam kondisi yang baru. Ada satu hal yang muncul dalam booming batu akik ini yang tidak bisa kita abaikan yakni adanya persentuhan langsung lokalitas dengan pasar, persentuhan itu telah melahirkan interaksi global desa dengan pasar. Kuasa pasar akhirnya menentukan terhadap kondisi sosial, kondisi lingkungan dan seterusnya. Oleh sebab itu, pasar yang menentukan ini tidak mengherankan terjadinya ekploitasi besarbesaran terhadap alam untuk mendapatkan booming di pasar itu. Dalam hal ini, jika tata kelakuan manusia dalam mencari batu akik tidak diberi penyadaran jelas memperpanjang terjadinya krisis global terhadap alam.

Oleh sebab itu, tata kelakuan manusia yang dikuasai oleh pasar berkonstribusi mewujudkan kerusakan alam. Sehubungan dengan konteks ini, Giddens (2000: xii-xiv), menyebutkan kuasa pasar tak akan terbendung mempengaruhi gaya, pikiran manusia. Dalam pengaruh itu perlu dilakukan pengawasan prilaku dalam penguasaan yang bersentuhan langsung dengannya.

\section{BATU AKIK GAYA SOSIAL GLOBAL YANG MENINDAS}

Di balik kondisi yang muncul dari booming batu akik adalah adanya pemahaman sosial yang harus dimaknai. Pemahaman sosial itu berupa keadaan-keadaan prilaku dan interaksi yang dikonstruksi oleh manusia pencinta batu akik di tengah-tengah kehidupan sosialnya, karena adanya kesadaran kolektif yang digiring oleh pasar dengan berbagai desakan-desakan perubahan dialog, perubahan gaya penampilan dan seterusnya, semuanya itu berimplikasi pada ekonomi atau pasar.

Salah satu yang terjadi dibalik desakandesakan pasar itu adalah, munculnya pekerjapekerja industri dengan alat produksi sendiri yang disebut dengan tukang asah batu akik. Keberadaannya bisa ditemukan dengan mudah di tepi-tepi jalan atau di tempat-tempat lainnya. Dorongan kemunculan indutrialisasi mudah ini, akhirnya sangat membentuk pada hasrat sosial kolektifitas itu dan mengabaikan pada hasrat kenalan pasar lainnya. Tanpa iklan pun batu akik menjadi booming dengan gaya pemasaran yang tidak mengenal ruang waktu dan tempat itu.

Secara sosial, alat bantuk booming yang lain adalah jejaring sosial yang begitu leluasa membicarakan batu akik, sehingga kesadaran kolektif itu tertumpu pada batu akik. Kemudian kemunculan komunitas-komunitas batu akik pun tidak bisa diabaikan sebagai pendesainan prilaku dan interaksi sosial. Prilaku terlihat dari cara orang memahmi batu akik sampai pada gaya-gaya yang dimunculkan dalam gerak gerik seseorang, seperti terlihat adanya keserasian jemari-jemari bercincin dengan 
memakai permata batu akik. Dari prilaku misalnya, muncul komunitas-komunitas yang sangaja membangun prilaku akian yang mengalahkan pada pengenalan-pengenalan material yang lain di pasar. Mengalahkan lomba kicau burung dan bahkan mengalahkan isu-isu sosial. Hal ini dapat dilihat begitu hangatnya pembicaraan ota tentang batu akik itu.

Keterpukauan kolektif telah mengalahkan perhatian pada yang lain. Gaya sosial sudah ditindih oleh keberadaan keterpakuan kolektif kepada batu akik ini. Lintas lapisan sosial telah dipreteli oleh batu akik. Konsentrasi sosial berbatu akik ini ternyata melahirkan sebuah temporitas gaya yang menindih, menindih kesadaran terhadap yang lainnya sehingga ada kealfaan dalam mencermati sesuatu yang semula hangat menjadi perhatian.

Tidak hanya itu, kehadiran batu akik yang menjadi gaya kolektif ini ternyata juga telah melahirkan pasar-pasar buatan yang memadati ruang-ruang publik, seperti terjadinya pasar temporer batu akik di pinggirpinggir jalan. Dimana batu-batu dijual untuk memenuhi konsumsi pencinta batu akik. Ada persaingan pasar tanpa mengenal ruang dan waktu. Kondisi ini yang disebut oleh Storey (Barkes, 1999: 62) sebagai budaya populer, dimana ditumbuhkan dan dikembangkan dengan berbagai manipulasi tanpa sadar, bisa diperdagangkan dimana saja tanpa mengenal ruang dan waktu, bisa saja menghambat ruang publik seperti lahirnya pasar dadakan di pinggir jalan yang tidak terkontrol, kemudian orang-orang berdatangan memenuhi pasar itu. Akhirnya ruang publik tertindih dari peran dan fungsinya yang semestinya, sehingga apa yang dikatakan oleh Fakuyama (2001: 1-3) ada sesuatu yang berakhir dalam kehidupan manusia karena ditindih oleh kepentingan yang lain, minimal keseimbangan alam tertindih oleh kepentingan pasar batu akik yang booming.

Kondisi-kondisi sosial yang muncul itu bisa juga disebut dengan era baru seperti yang diulas oleh Hall dan Jaques (Barker, 1999: 136). Dimana situasi dan suasana kolektif sudah terkosentrasi pada satu keadaan, sehingga diskusi dan corak-corak penampilan digelantungi oleh asesoris yang dibangun dalam kekolektifan itu. Orang-orang merasa tidak cukup berpenampilan tanpa ada asesoris kolektif tersebut, batu akik mewakili hal yang demikian itu sehingga aseseoris-asesoris dalam wujud batu akik mendominasi hadir dalam penampilan, minimal terlihat di satu jari. Penindasan gaya ini, amat terlihat sekarang ini dimana dengan mudah menemukan jemarijemari pakai batu akik tersebut yang dipakai oleh lintas batas dan kelas.

Namun, bagaimana pun juga kalau dilihar dari realitas yang terjadi analisis Weber tentang boomingnya batu akik disebabkan oleh adanya tindakan sosial dan tindakan sosial itu berdiffusi menjadi tindakan kolektif. Tindakan sosial itu menurut Weber ada empat, rasionalitas instrumental, rasionalitas nilai, tradisonal dan afektif (Ritzer, 2005:36-38). Dalam realitas dan fenomena yang terjadi dapat difahami bahwa booming batu akik sepertinya mengikuti tindakan sosial tradisional, kebiasaan yang dibangun mengulang apa yang dipresentasikan oleh nenek moyang. Hal ini dapat dilihat dari interpretasi yang dikembangkan dalam memahami batu akik disamping mempertimbangkan keindahannya.

Eksistensi batu akik dalam kontensk ini bisa disebut sebagai ekonomi gelembung yang diperkenalkan oleh Naisbitt (1996; 25-26) yang dulu pernah hilang sekarang muncul dengan sangat booming yang menggiring kepada gaya kolektif dunia sosial manusia. Pasar menjadi penentu dalam penggelembungan 
itu dan pasar pula sebenarnya mendesainnya dimensi-dimensi sosial manusia, sehingga dalam rentang waktu yang cepat terasa ada yang terhilang dan tertindih, bahkan logisitas manusia pun ikut tertindih oleh kewarasan, seperti batu akik bisa dijadikan sebagai alat penolong, penyembuh penyakit, pelaris dan seterusnya. Pada hal dalam masyarakat global, logisitas itu merupakan kedigdayaan sebagai ciri khas manusia modern dalam menta ruang dan waktunya.

\section{KESIMPULAN}

Memahami booming batu akik yang terjadi saat sekarang, sepertinya memahami sebuah fenomena paradok di arus global. Gaya yang terguras oleh zaman, kemudian berbalik pada trend yang lalu. Dimana ada kesadaran kolektif yang diarahkan secara sadar dan kemudian diterima secara kolektif pula. Kesadaran kolektif itu dipermainkan oleh pasar dan image tentang sebuah batu dimunculkan dengan berbagai interpretasi yang sengaja dikonstruksi untuk menggiring kesadaran kolektif itu. Akhirnya, kegilaan terhadap batu akik menjadi-jadi mengalahkan isu-isu yang lain di ranah publik.

Batu akik menjadi gaya dan style yang memuat interpretasi-interpetasi kelokalan dan kemistikan. Kondisi itulah, yang belum bisa dihilangkan dari kebudayaan masyarakat kita sekalipun zaman dan era sudah berubah mistik dan arena lokalitasnya masih melekat dalam pencetusan gayanya. Namun perlu pula di sadari, bahwa batu akik yang dibungkus dengan lokalitas dan mistis itu mengglobal karena adanya permainan pasar.

\section{DAFTAR PUSTAKA}

Berker, Chris. 1999. Culture Studies; Teori dan Praktek. Bentang, Jogjakarta

Capra, Fritjof. 2004. Titik Balik Peradaban. Bentang., Jokjakarta.

Fakuyama, Francis. 2001. Kemenangan Kapitalisme dan Demokrasi Liberal. Qalam. Yogyakarta.

Giddens, Anthony. 2000. The Thied Way, Jalan Ketiga Pembaruan Demokrasi. PT. Gramedia Pustaka Utama. Jakarta.

Johnson, P. Doyle. Teori Sosiologi Klasik dan Modern. PT. Gramedia. Jakarta.

Khaldun, Ibnu. 2011. Muqaddimah. (Terj. Ahmedia Thoha). Pustaka Firdaus, Jakarta.

Marzali. Amri. 2007. Antropologi dan Pembangunan Indonesia. Kencana Prenada Media Group. Jakarta.

Nasibitt, Jhon. 1994. Global Paradoxs. Bina Rupa Aksara. Jakarta.

Naisbitt, Jhon. 1996. Megatrends Asia. PT. Gramedia Pustaka Utama. Jakarta.

Ritzer, George \& Goodman, 2005. Teori Sosiologi Modern. Kencana, Jakarta

Sutrisno \& Putranto. 2005. Teori-Teori Kebudayaan. Kanisius. Yogyakarta.

Taleb, Nassim N., 2009. The Black Swan Rahasia Terjadinya Peristiwa-Peristiwa Langka Yang Tak Terduga. Gramedia, Jakarta 


\title{
PANDUAN PENULISAN
}

\author{
Jurnal Mamangan Edisi III, Program Studi Pendidikan Sosiologi \\ STKIP PGRI Sumatera Barat
}

\section{a. Pendahuluan}

Setiap tulisan ilmiah, baik berupa essay, makalah, jurnal, laporan penelitian dan buku memiliki karakteristik tersendiri sesuai dengan selera penulis, penerbit, sponsor penelitian dan atau aturan-aturan tertentu sesuai dengan ruang dan waktu dimana tulisan dibuat oleh penulis. Selain itu, karakteristik sebuah tulisan ilmiah juga menggambarkan karakter institusi dimana sebuah tulisan diterbitkan. Meskipun demikian sebuah tulisan ilmiah tentulah memiliki standar minimum yang harus dipenuhi. Standar minimum tersebut terkait dengan substansi isi dan aspek teknis dalam penulisannya. Dengan dua standar yang ada sebuah tulisan ilmiah dapat dipertanggungjawabkan secara akademis.

Mengikuti logika umum penulisan ilmiah, ragam bentuk dan karakteristik tulisan ilmiah yang berlaku umum dalam khasanah akademik maupun praktis sebagaimana diuraikan di atas, untuk menjadikan Jurnal Mamangan sebagai sebuah karya ilmiah, program studi sosiologi juga menginginkan jurnal Mamangan memiliki karakter yang kuat dan spesifik dalam kerangka isu dan bentuk penulisan. Karakter dan spesifikasi yang kuat antara lain dapat diatur melalui dua hal, pertama substansi isi. Substansi isi diatur melalui tema dan isu utama tulisan pada masing-masing edisi jurnal yang ditetapkan oleh redaksi. Paling tidak, tulisan yang ada dalam satu edisi memiliki isu utama yang sama dalam kacamata disiplin ilmu yang berbeda, sehingga jurnal melahirkan pembahasan isu dengan multiparadigma. Dengan khasanah ilmu yang berbeda tersebut kemudian isu utama jurnal pada masing-masing edisi akan memiliki perspektif yang banyak dan isu utama dapat dibahas secara utuh dan kokoh.

Kedua pengaturan teknis dan sistematika penulisan. Pengaturan teknis dan sistematika penulisan bertujuan untuk menyamakan pola dan kerangka penulisan yang hendak dimuat dalam jurnal. Pengaturan teknis dan sistematika penulisan ini sekaligus bertujuan untuk membantu penulis dalam mengerangkakan tulisan ilmiah yang akan dikirimkan ke Jurnal Mamangan Diharapkan dengan pengaturan format makalah secara substansi dan teknis, jurnal Mamangan memiliki karakter yang kuat dan khas dalam secara ilmiah.

\section{b. Tujuan}

Pengaturan teknis dan format penulisan ini tidak berpretensi untuk menggurui atau bahkan mengajarkan kepada partisipan tentang bagaimana cara menulis ilmiah yang baik dan benar, tapi pengaturan format ini tidak labih dari sekedar menyamakan persepsi tentang substansi dan format tulisan yang diinginkan dalam jurnal yang direncanakan. Sehingga, penulisan panduan ini hanya sebatas untuk menyamakan pola dan kerangka dasar penulisan untuk tema yang sama dalam kacamata yang berbeda.

\section{c. Teknis dan Format Penulisan}

1. Naskah merupakan karya ilmiah original penulis dan tidak mengandung unsur plagiarisme;

2. Naskah ditulis dalam Bahasa Indonesia atau Bahasa Inggris;

3. Naskah menggunakan istilah yang baku serta bahasa yang baik dan benar;

4. Naskah diketik dengan program Microsoft Word, huruf Cambria, ukuran 12 pts, spasi 1, kertas ukuran A4, 12-17 halaman; 
5. Naskah diserahkan dalam bentuk soft copy ke email redaksi, redaksimamangan@gmail.com

6. Sistematika penulisan artikel:

a) Judul: maksimal 14 kata dalam bahasa Indonesia dan 12 kata dalam bahasa Inggris; ditulis dengan huruf kapital, ukuran 12 pts;

b) Nama Penulis: tanpa mencantuman gelar akademik. Artikel yang ditulis oleh lebih dari satu orang, harus mencantumkan setiap nama penulis, dengan meletakkan nama penulis utama di urutan awal; nama penulis diikuti dengan mencantumkan alamat email.

c) Lembaga: dicantumkan di bawah alamat email setelah nama penulis;

d) Abstrak dan Kata Kunci (keyword): Abstrak ditulis dalam dua bahasa, yaitu Bahasa Inggris dan Bahasa Indonesia. Panjang abstrak maksimal 200 kata, dan kata kunci (keyword) maksimal 5 kata. Abstrak memuat tujuan, metode, dan hasil penelitian;

e) Pendahuluan: berisi latar belakang masalah, konteks penelitian, telaah pustaka, dan tujuan penelitian. Seluruh bagian pendahuluan diuraikan secara terintegrasi dalam bentuk paragraf-paragraf;

f) Literature review atau kerangka teori : bagian ini merupakan uraian penulis tentang penelusuruan penelitian terdahulu atau kajian teoritis yang digunakan dalam artikel. Literature review atau kerangka teori maksimal 2 halaman.

g) Metode Penelitian: berisi uraian tentang rancangan teknis-prosedural penelitia, berupa setting lokasi penelitian, jenis data penelitian, teknik pengumpulan data, analisis data, dan penyajian data. dapat juga ditambahkan paradigma penelitian;

h) Hasil/ Temuan Penelitian/ Analisis: merupakan hasil analisis yang berkaitan dengan pertanyaan penelitian. Setiap temuan data penelitian haur dibahas. Pembahasan berupa pemaknaan, interpretasi, dan pendekatan atau pembacaan teori terhadap data yang diperoleh;

i) Simpulan: bagian ini terdiri dari temuan penelitian yang merupakan jawaban atas pertanyaan penelitian atau merupakan intisari dari hasil pembahasan. Kesimpulan disajikan dalam bentuk paragraf;

j) Daftar Pustaka: hanya memuat sumber-sumber yang dirujuk, dan setiap sumber yang dirujuk harus tercantum dalam daftar pustaka. Rujukan berupa sumber-sumber primer yang terdiri dari hasil penelitian, artikel jurnal, dan penelitian sripsi, tesis dan disertasi;

k) Biodata Penulis: berupa nama, tempat tanggal lahir, alamat, lembaga, alamat email, nomor telepon/HP, pendidikan dan pekerjaan, serta publikasi karya/tulisan terbaru.

\section{Contoh penulisan Daftar Pustaka:}

\section{Buku:}

Anderson, D.W., Vault, V.D \& Dickson, C.E. Problems dan Prospects for the Decades Ahead: Competency Based Teacher Education. Berkeley: McCutchan Publishing Co, 1999.

\section{Buku kumpulan artikel:}

Saukah, A. \& Waseso, M.G. (Eds.). Menulis Artikel untukJurnal Ilmiah (edisi ke-4, cetakan ke-1). Malang: UM Press, 2002.

\section{Artikel dalam buku kumpulan artikel:}

Russel, T. An Alternative Conception: Representing Representation. Dalam P.J. Black \& A. Lucas (Eds.), Children's Informal Ideas in Science (hal. 62-84). London: Routledge, 1998.

\section{Artikel dalam jurnal atau majalah:}

Kansil, C.L. Orientasi Baru Penyelenggaraan Pendidikan Program Profesional dalam Memenuhi Kebutuhan Dunia Industri. Transpor, XX (4): 57-61, 2002.

\section{Artikel dalam koran:}

Pitunov, B. Sekolah Unggulan ataukah Sekolah Pengunggulan? Kompas, hlm. 4 \& 11, 13 Desember, 2002.

\section{Tulisan/berita dalam koran (tanpa nama pengarang):}

Republika. Wanita Kelas Bawah Lebih Mandiri, hal. 3, 22 April 2013. 


\section{Dokumen resmi:}

Pusat Pembinaan dan Pengembangan Bahasa. Pedoman Penulisan Laporan Penelitian. Jakarta: Depdikbud. Undangundang Republik Indonesia Nomor 2 tentang Sistem Pendidikan nasional. Jakarta: PT Armas Duta Jaya, 1978.

\section{Buku terjemahan:}

Ary, D., Jacobs, L.C. \& Razavieh, A. 1976. Pengantar Penelitian Pendidikan. Terjemahan oleh Arif Furchan. Surabaya: Usaha Nasional, 1982.

\section{Skripsi, Tesis, Disertasi, Laporan Penelitian:}

Kuncoro, T. Pengembangan Kurikulum Pelatihan Magang di STM Nasional Malang Jurusan Bangunan, program Studi Bangunan Gedung: Suatu Studi Berdasarkan Kebutuhan Dunia Usaha Jasa Konstruksi. Tesis. Malang: PPS IKIP MALANG, 1996.

\section{Makalah seminar, lokakarya, penataran:}

Waseso, M.G. Isi dan Format Jurnal Ilmiah. Makalah. Seminar Lokakarya Penulisan Artikel dan Pengelolaan Jurnal Ilmiah, Universitas Lambung Mangkurat, Banjarmasin, 9-11 Agustus, 2001.

\section{Internet (karya individual):}

Hitchcock, S., Carr, L. \& Hall, W. A Survey of STM Online Journals, 1990-1995: The Calm before the Storm, 1996. (http:// journal.ecs.soton.ac.uk/survey/survey.html,diunduh 12 Juli 2011).

\section{Internet (artikel dalam jurnal online):}

Kumaidi. 1998. Pengukuran Bekal Awal Belajar dan Pengembangan Tesnya. Jurnal Ilmu Pendidikan. (Online), Jilid 5, No. 4, (http://www.malang.ac.id, diunduh 20 Januari 2011).

\section{Internet (bahan diskusi):}

Wilson, D. 20 November 1995. Summary of Citing Internet Sites. NETTRAIN Discussion List, (Online), (NETTRAIN@ ubvm.cc.buffalo.edu, diunduh 22 Oktober 2010.

\section{Internet (email pribadi):}

Naga, D. S. (ikip-jkt@indo.net.id). 1 Oktober 2011. Artikel untuk Turast. E-mail kepada Subhan Ajrin (subhanajrin@ gmail.com). 


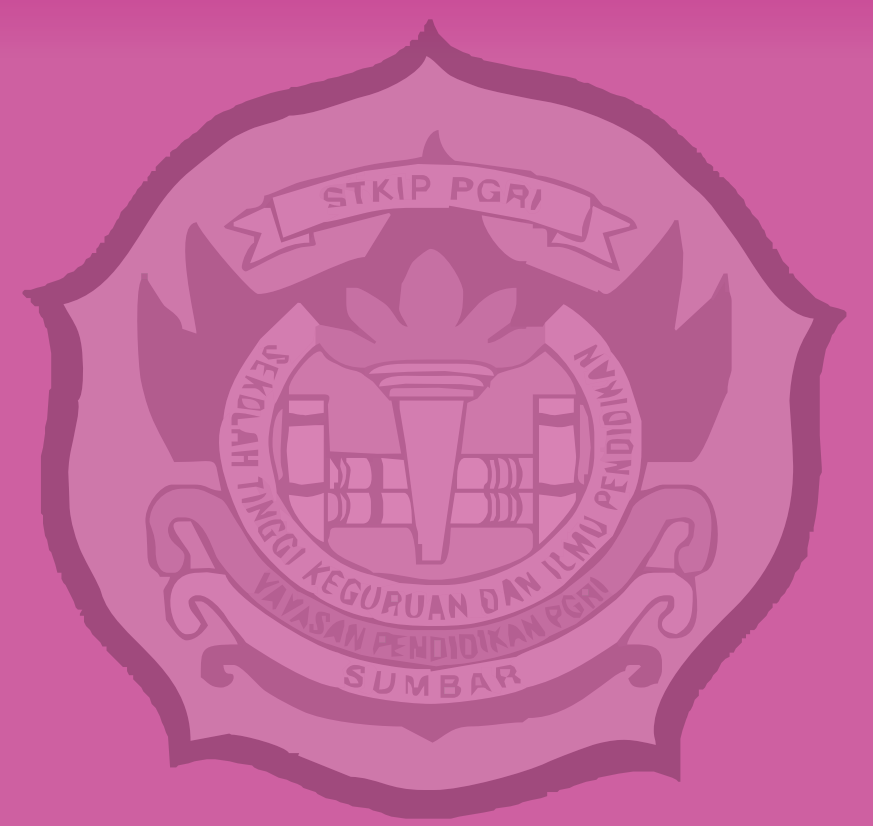

Penerbit:

Laboratorium Program Studi Pendidikan Sosiologi, STKIP PGRI Sumbar Alamat: Kampus STKIP PGRI, Jl. Gunung Pangilun, Padang, Sumatera Barat Email: redaksimamangan@gmail.com 